\title{
Bovine Bone Matrix Action Associated With Morphogenetic Protein in Bone Defects in Rats Submitted to Alcoholism
}

\author{
Acción de la Matriz Ósea Bovina Asociada a la Proteína Morfogenética \\ en Defectos Óseos en Ratones Sometidos a Alcoholismo \\ "Rogério Leone Buchaim; *Jesus Carlos Andreo; *Antonio de Castro Rodrigues; **Daniela Vieira Buchaim; \\ ${ }^{* *}$ Domingos Donizeti Roque; ${ }^{* *}$ José Sidney Roque \& *** Geraldo Marco Rosa Júnior
}

BUCHAIM, R. L.; ANDREO, J. C.; RODRIGUES, A. C.; BUCHAIM, D. V.; ROQUE, D. D.; ROQUE, J. S. \& ROSA-JÚNIOR, J. M. Bovine bone matrix action associated with morphogenetic protein in bone defects in rats submitted to alcoholism. Int. J. Morphol., 30(1):266-271, 2012.

SUMMARY: Extended excessive alcohol use causes changes in bone tissue, thus affecting osteogenesis. The objective of this study was to evaluate if demineralized bone matrix (Gen-ox $\left.{ }^{\circledR}\right)$ associated with bone morphogenetic protein $(\mathrm{Gen}$-pro®) changes bone neoformation in rats submitted to experimental alcoholism. Forty male rats (Rattus norvegicus) were separated into 2 groups of 20 animals each: Group E1, which received ethyl alcohol at 25\% and had the surgical cavity filled in only with blood clot; and Group E2, which received ethyl alcohol at $25 \%$ and had the surgical cavity filled in with demineralized bovine cortical bone associated with bone morphogenetic protein. The animals were submitted to a three-week period of gradual adaptation to alcohol, and then continued receiving alcohol at $25 \%$ for 90 days, when the surgical cavity was made. After the surgery, the animals continued consuming alcohol until reaching the sacrifice periods of 10,20,40, and 60 days, when the tibias were removed for histological processing. Results showed that surgical cavity repair and bone marrow reorganization occurred faster in Group E1 than in Group E2. At the end of the experiment, it was observed that animals in Group E2 had thick bony trabeculae surrounding the implanted material particles and a small area of connective tissue in the surface region. In conclusion, the implanted material did not accelerate bone neoformation, rather it served as a structure for osteogenesis.

KEY WORDS: Bone repair; Alcoholism; Xenograft; Bone morphogenetic proteins.

\section{INTRODUCTION}

The use of bone morphogenetic proteins (BMPs) in reconstruction procedures to induce osteogenesis is an alternative for autogenous and alogenous bone grafts, thus reducing the risk of complications associated to surgeries and donor limitations. After lyophilization, BMPs are linked to a carrier, which has the purpose of preserving the surgical cavity for a longer period, as it would normally be rapidly resorbed by the organism. Therefore, one characteristic of these morphogenetic proteins is the need of a vehicle, which can be the demineralized bovine matrix (Damien et al., 1995; Tuominen et al., 2001; Ueda et al., 2001; Guimarães et al., 2004; Curi et al., 2008; Ho et al., 2010).

The effects of alcohol are not limited to one specific tissue; rather, they have a systemic and multifactor action. In bone tissue, alcohol reduces osteoblastic activity, generating low bone mass and increasing the rates of fracture among alcoholics, and contributes to the development of osteoporosis (GarciaSanchez et al., 1995; Buchaim et al., 2002; Gong \& Wezeman, 2004; Iwaniec et al., 2008).

Furthermore, alcohol causes changes at the molecular level of the Wnt/b-catenin signaling pathway, which is essential for the repair process. When repair is affected, it may cause a breakage of the differentiation of mesenquimal stem-cells, affecting bone tissue and callus formation. Hence, restoring or protecting the $\mathrm{Wnt} / \mathrm{b}$ catenin signaling pathway can improve the prognosis for fracture healing in patients with acute or chronic exposure to alcohol (Jung et al., 2011).

\footnotetext{
* Departament of Biological Science, Bauru School of Dentistry, University of São Paulo, Bauru, SP, Brazil.

** University of Marília, Marília, SP, Brazil.

**** Sacred Heart University, Bauru, SP, Brazil.
} 
The objective of this study was to observe if demineralized bovine bone matrix (Gen-ox $\left.{ }^{\circledR}\right)$ associated with bone morphogenetic protein (Genproß) changes bone neoformation in rats submitted to experimental alcoholism, in the periods of 10, 20, 40, and 60 days, based on histologic and morphometric analysis.

\section{MATERIAL AND METHOD}

Animal Protocol and Surgical Procedure. Forty adult male Wistar rats (Rattus norvegicus), mean weight $290 \mathrm{~g}$, were divided into two groups of 20 rats each, as follows: Group E1, which received ethyl alcohol at $25 \%$, and surgical cavity filled in only with blood clot; Group E2, which received ethyl alcohol at 25\%, and surgical cavity filled with demineralized bovine cortical bone associated with bone morphogenetic protein (Gen-ox® e Gen-pro®; Genius, Baumer S.A., Mogi Mirim, SP, Brazil).

Both groups were first submitted to a gradual adaptation to ethyl alcohol until reaching the maximum level of $25 \%$, which was maintained for 90 days. After this, the experimental surgery was performed. After the surgery, the animals continued receiving alcohol until they were sacrificed, according to the specific periods of each group.

The rats received general anesthesia via an intramuscular injection with Tiletamine hydrochloride (125.0 mg) associated with Zolazepam hydrochloride (125.0 mg) at the dosage of $50.0 \mathrm{mg} / \mathrm{kg}$ IM.

After shaving the area, a $20 \mathrm{~mm}$ linear incision was made in the cranium-caudal direction of the left pelvic limb, and a cavity was made on the tibia using surgical trephine ( $2 \mathrm{~mm}$ diameter) and irrigation with sodium chloride solution at $0.9 \%$.

All cavities in Group E1 animals were filled with blood cloth, whereas in Group E2 the cavities were filled with inorganic demineralized bovine cortical bone associated with bone morphogenetic protein (bovine bone particles- BBP) immersed in saline solution. The tissues were repositioned and sutures were made. Five rats of each group were sacrificed after 10, 20, 40, and 60 days after surgery, by an injection containing an excessive amount of the aforementioned anesthetic.
Histologic and Morphometric Analysis. The tibias were fixed at buffered formaldehyde at $10 \%$ for 24 hours, decalcified and embedded in paraffin (following routine laboratory procedures). Longitudinal six micrometerthick cuts were made, resulting in semi-serial cuts, which were stained folowing Masson's trichrome protocol.

The amount of bone tissue and connective tissue formed was obtained using a 100-point quadrilateral grid system coupled to the ocular micrometer of a light microscope, according to the principle of Delesse mentioned by Mandarim-de-Lacerda (1999).

Statistical Analysis. The collected data were submitted to one-way ANOVA followed by Tukey's test. The data were also submitted to Student's t test to allow for group comparisons. For all analyses, P was considered statistically significant if $<0.05$.

\section{RESULTS}

Histological Analysis. In Group E1 (10 days), the surgical cavity is partially filled with thin bone trabeculae (Fig. 1A). In Group E2, the implanted material takes over most of the surgical cavity, and bone tissue formation is observed in small peripheral areas (Fig. 1B). In Group E1 (20 days) the surgical cavity was partially repaired, with incomplete formation of new cortical bone (Fig. 2A), whereas in Group E2 there was initial bone neoformation surrounding the implanted material (Fig. 2B). In the 40-day period, the surgical cavity in Group E1 was repaired with the reorganization of the bone marrow (Fig. 3A), and in Group E2 there were bone trabeculae organized around the implanted material (Fig. 3B). In the last period, the cortical bone in Group E1 was completely repaired (Fig. 4A), and in Group E2, in the superficial surgical area, thick trabeculae are observed around implanted material particles and the small connective tissue area (Fig. 4B).

\section{Histometric Analysis.}

Bone tissue area: A comparison between both groups, considering the different periods, showed a statistically significant difference in the periods 10 and 60 days (Fig. 5A).

Connective tissue area: A comparison between both groups, considering the different periods, showed a statistically significant difference in the periods 20,40, and 60 days (Fig. 5B). 

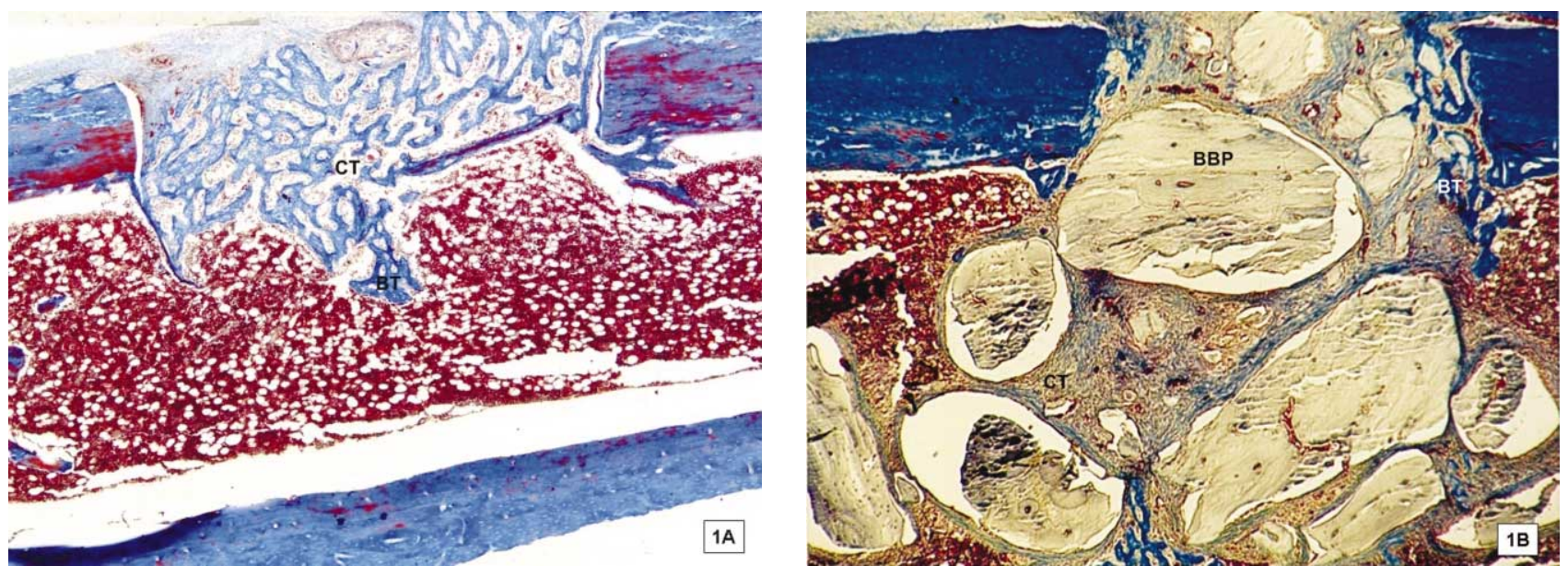

Fig. 1A (Group E1) and Fig. 1B (Group E2) - 10 days: (CT) Connective Tissue; (BT) Bone Tissue; (BBP) Bovine Bone Particles.
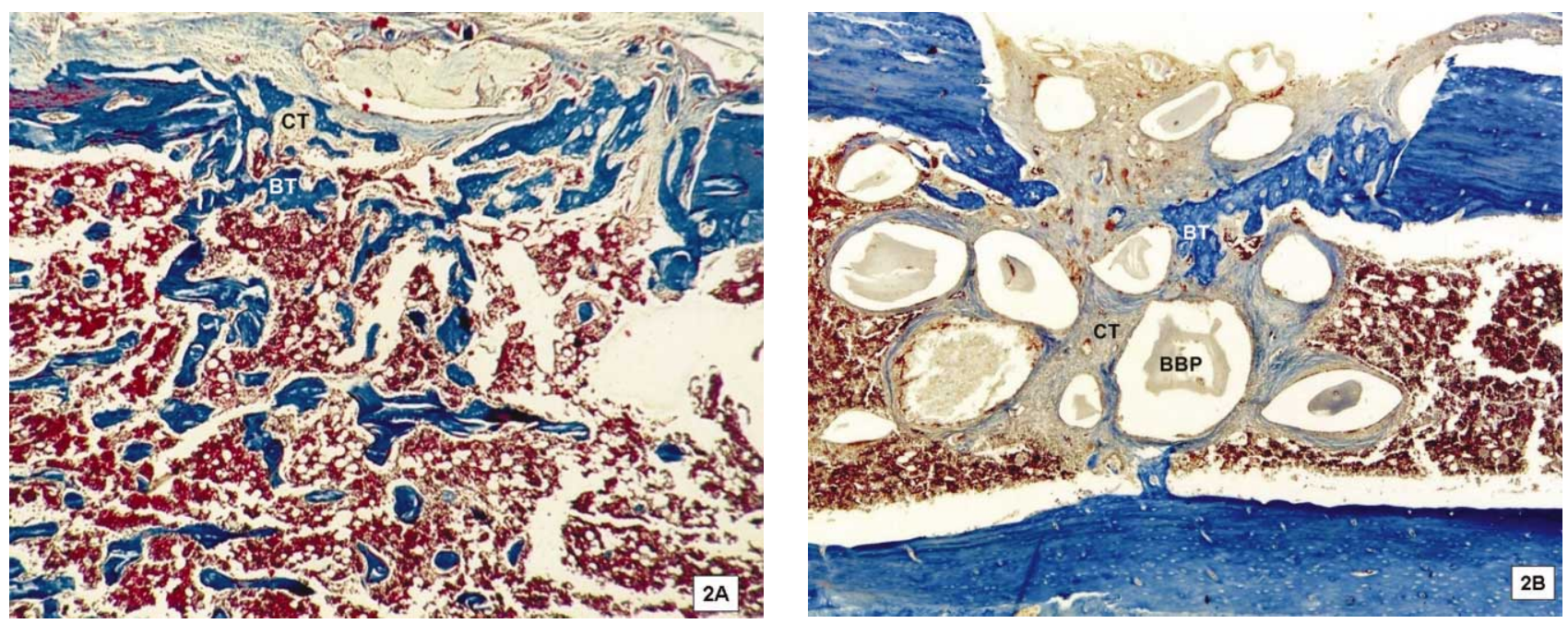

Fig. 2A (Group E1) and Fig. 2B (Group E2) - 20 days: (CT) Connective Tissue; (BT) Bone Tissue; (BBP) Bovine Bone Particles.
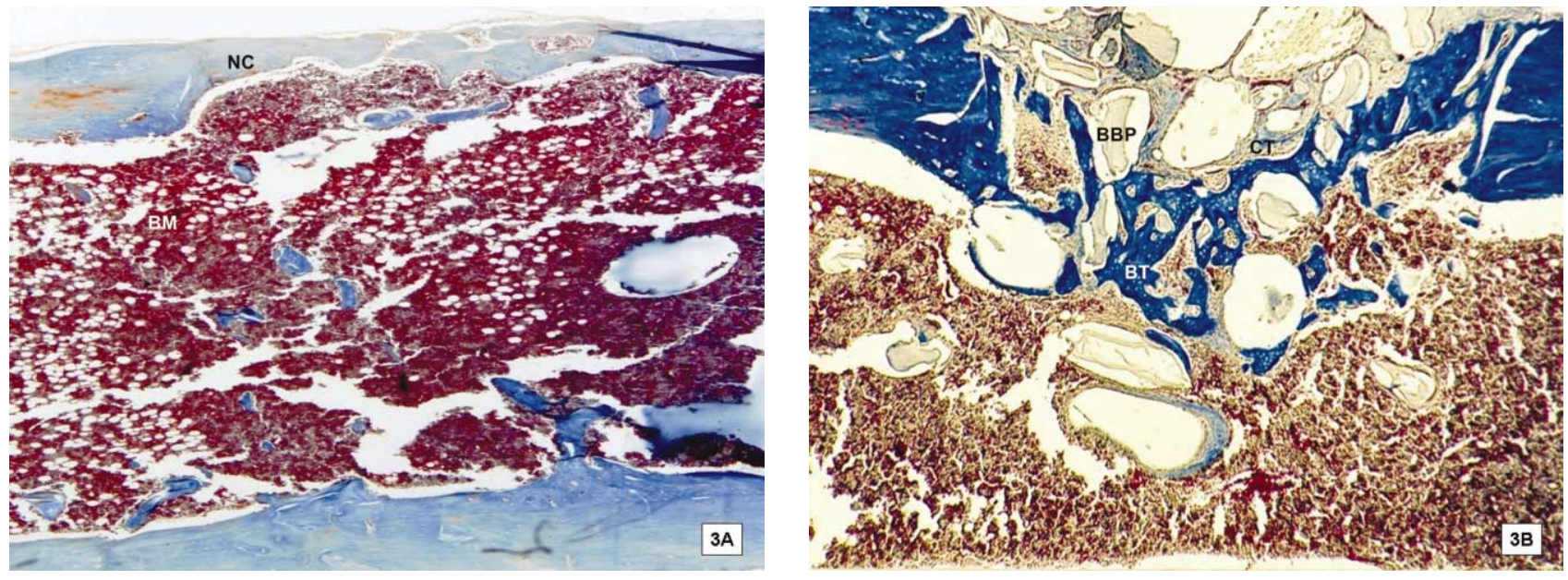

Fig. 3A (Group E1) and Fig. 3B (Group E2) - 40 days: (NC) Newly Cortical; (BM) Bone Marrow; (CT) Connective Tissue; (BT) Bone Tissue; (BBP) Bovine Bone Particles. 

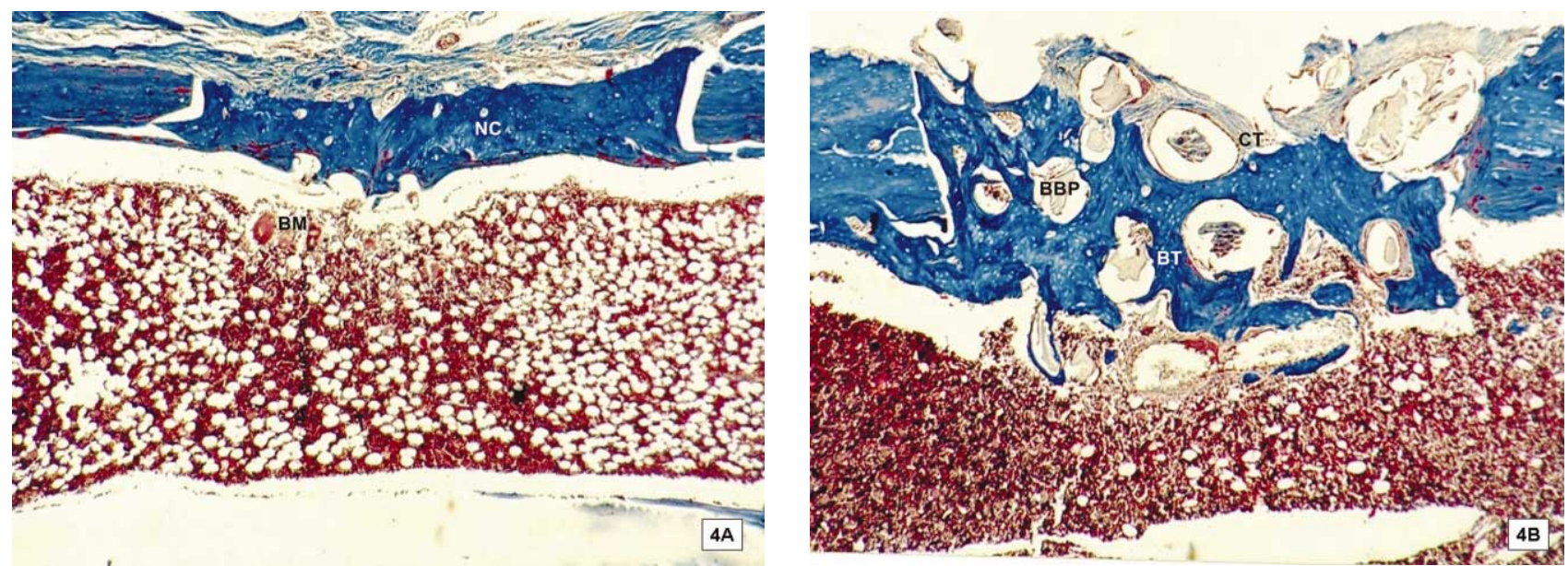

Fig. 4A (Group E1) and Fig. 4B (Group E2) - 60 days: (NC) Newly Cortical; (BM) Bone Marrow; (CT) Connective Tissue; (BT) Bone Tissue; (BBP) Bovine Bone Particles.

\section{Area of bone tissue between the groups E1 and E2}

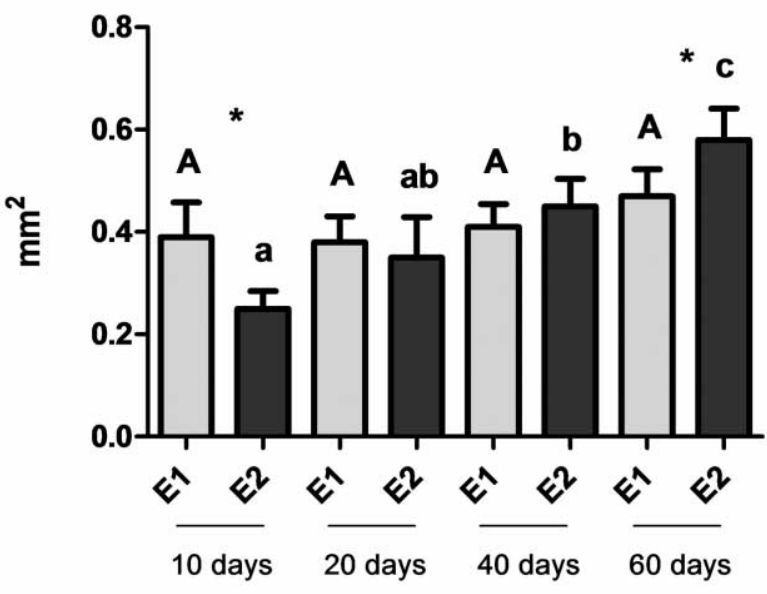

Area of connective tissue between the groups E1 and E2

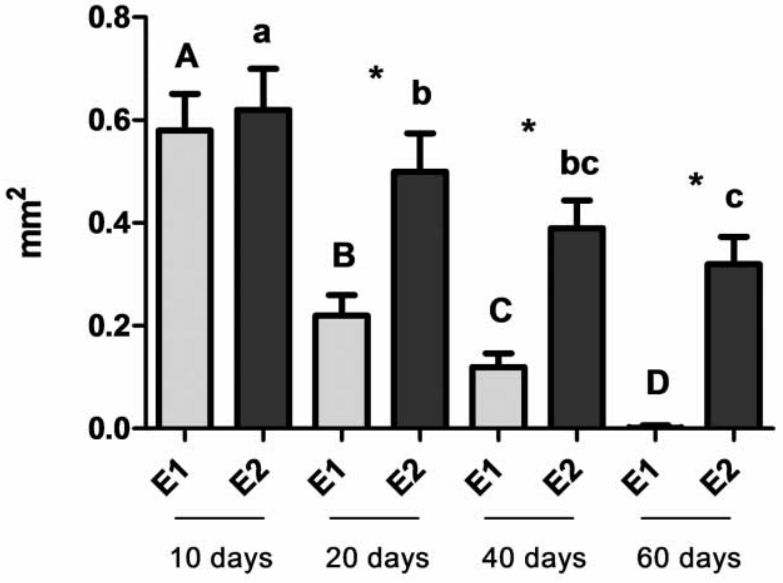

Fig. 5A and Fig. 5B - Mean values of bone tissue and connective tissue area (mm2), comparing the groups E1 and E2 in different periods. Same letters indicate no statistically significant difference. The different letters indicate statistically significant difference. Asterisks indicate statistically significant difference between groups in the same period. 


\section{DISCUSSION}

The association of organic bovine bone matrix with hydroxyapatite, to favor the repair of bone defects made on rat skulls, promoted a greater number of osteoblasts and neoformed bone during the 60-day repair period. This fact was noted in the present experiment, in which 60 days after the experimental surgery there was partial repair of the surgical cavity and almost complete neocortical bone, with a small presence of fibrous connective tissue and large neoformed bone trabeculae in the areas adjacent to the implanted material (Braz et al., 2003; Martins et al., 2004).

An experiment that used the same BMP, but without associating with bone matrix, concluded that using BMPbHA to treat skull bone defects in rats promotes the formation of foreign body granulomatous reaction that strongly inhibits bone neoformation. This suggests that microgranular synthetic hydroxyapatite is not a good carrier for BMPs to express their inductor potential (Peel et al., 2003; Ferreira et al., 2004; Gerbi et al., 2005).

The alcohol concentration used in this research was based on previous studies, in which experimental groups were submitted to three alcoholic diets $(6 \%, 15 \%$, and $25 \%)$ that showed adverse effects to bone tissue, especially in the group with the highest alcohol concentration (Buchaim et al., 2009; Broulik et al., 2010).

In Group E1, in the 10-day period, there is greater concentration of neoformed bone in the superficial surgical area. In relation to the other analyzed periods, there was reorganization of the marrow region, and the amount of bone tissue is due to the neoformed cortical bone.

In Group E2, the amount of bone tissue in the initial periods is smaller than that of Group E1. It should be noted that every biomaterial placed in a bone defect generates an initial inflammatory response, greater than that observed in defects filled in with blood clot (Marzola et al., 1996; Buchaim et al., 2007; Marin et al., 2007).

The larger amount of bone tissue in Group E2, in the 60-day period, occurs because of the presence of neoformed bone tissue in the broken cortical bone and in the superficial marrow region, involving graft particles, in most specimens. Hence, it is concluded that the implanted material serves as a structure for osteogenesis, but does not accelerate bone repair.

BUCHAIM, R. L.; ANDREO, J. C.; RODRIGUES, A. C.; BUCHAIM, D. V.; ROQUE, D. D.; ROQUE, J. S. \& ROSA-JÚNIOR, J. M. Acción de la matriz ósea bovina asociada a la proteína morfogenética en defectos óseos en ratones sometidos a alcoholismo. Int. J. Morphol., 30(1):266-271, 2012.

RESUMEN: El abuso prolongado del alcohol produce alteraciones en el tejido óseo, interfiriendo en el proceso de la osteogénesis. El estudio tiene como objetivo evaluar si la matriz ósea bovina desmineralizada (Gen-ox®) asociada a la proteína morfogenética ósea (Gen-proß) altera la neoformación ósea en ratones sometidos a alcoholismo experimental. Fueron utilizados 40 ratones machos (Rattus norvegicus), separados en dos grupos de 20 animales cada uno: Grupo E1, que recibió alcohol etílico a 25\% con cavidad quirúrgica rellenada solamente por coágulo sanguíneo, y Grupo E2, que recibió sólo alcohol etílico a $25 \%$ con cavidad quirúrgica rellenada con hueso bovino desmineralizado cortical asociado a proteína morfogenética ósea. Después de 3 semanas de adaptación gradual al alcohol, los animales continuaron recibiéndolo en concentración de $25 \%$ por 90 días, cuando fue realizada la cavidad quirúrgica. Luego de la cirugía, los animales continuaron la ingestión alcohólica hasta los períodos de sacrificio de 10, 20, 40 y 60 días, cuando las tibias fueron removidas para su procesamiento histológico. Los resultados mostraron que en el Grupo E1 hubo reparación de la cavidad quirúrgica y reorganización de la médula ósea en un menor lapso temporal que en el Grupo E2. En el período final del experimento, se observó en los animales del Grupo E2 la presencia de trabéculas óseas espesas alrededor de las partículas de material implantado y pequeña área de tejido conjuntivo en la región superficial. Se puede concluir en que el material implantado no aceleró el proceso de neoformación ósea, sirviendo como estructura de base para generar osteogénesis.

PALABRAS CLAVE: Reparación ósea; Alcoholismo; Injerto xenogénico; Proteína morfogenética ósea.

\section{REFERENCES}

Braz, F.; Rahal, S. C.; Rocha, N. S.; Taga, E. \& Biasi, F. Emprego de matriz óssea orgânica bovina e hidroxiapatita no reparo de defeito induzido em crânio de ratos. Acta Cir. Bras., 18(1):19, 2003.
Broulik, P. D.; Vondrova, J.; Ruzicka, P.; Sedlacek, R. \& Zima, T. The effect of chronic alcohol administration on bone mineral content and bone strength in male rats. Physiol. Res., 59:599604, 2010. 
Buchaim, R. L.; Roque, D. D.; Roque, J. S.; Toledo Filho, J. L.; Andreo, J. C. \& Okamoto, T. Gen-Phos implant in surgical cavities perfomed in the tíbia of rats submitted to experimental chronic alcoholism. A microscopic study. Rev. FOB., 10(1):17-22, 2002.

Buchaim, R. L.; Goissis, G.; Andreo, J. C.; Roque, D. D.; Roque, J. S.; Buchaim, D. V. \& Rodrigues, A. C. Biocompatibility of anionic collagen matrices and its influence on the orientation of cellular growth. Cienc. Odontol. Bras., 10(3):12-20, 2007.

Buchaim, R. L.; Buchaim, D. V.; Andreo, J. C.; Roque, D. D.; Roque, J. S. \& Rodrigues, A. C. Effects of three alcoholic diets on the bone repair in the tibia of rats. Cienc. Odontol. Bras., 12(2):17-23, 2009.

Curi, V.; Azoubel, R.; Lopes, R.A.; Martins, A. T.; Di Matteo, M. A. S. \& Kassis, E. N. Histometric study of alveolar bone in rats submitted to ethanol during lactation. Int. J. Morphol., 26(4):945-50, 2008.

Damien, C. J.; Parsons, J. R.; Prewett, A. B.; Huismans, F.; Shors, E. C. \& Holmes, R. E. Effect of demineralized bone matrix on bone growth within a porous HA material: a histologic and histometric study. J. Biomater. Appl., 9(3): 275-88, 1995.

Ferreira, G. R.; Cestari, T. M.; Granjeiro, J. M. \& Taga, R. Lack of repair of rat skull critical size defect treated with bovine morphometric protein bound to microgranular bioabsorbable hydroxyapatite. Braz. Dent. J., 15(3):175-80, 2004.

García-Sanchez, A.; Gonzalez-Calvin, J. L.; Diez-Ruiz, A.; Casals, J. L.; Gallego-Rojo, F. \& Salvatierra, D. Effect of acute alcohol ingestion on mineral metabolism and osteoblastic function. Alcohol Alcohol., 30(4):449-53, 1995.

Gerbi, M. E.; Pinheiro, A. L.; Marzola, C.; Limeira Júnior, F. de A.; Ramalho, L. M.; Ponzi, E. A.; Soares, A. O.; Carvalho, L. C.; Lima, H. V. \& Gonçalves, T. O. Assessment of bone repair associated with the use of organic bovine bone and membrane irradiated at $830 \mathrm{~nm}$. Photomed. Laser Surg., 23(4):382-8, 2005.

Gong, Z. \& Wezeman, F. H. Inhibitory effect of alcohol on osteogenic differentiation in human bone marrow-derived mesenchymal stem cells. Alcohol Clin. Exp. Res, 28(3):46879, 2004.

Guimarães, M. C. M.; Passanezi, E.; Sant'ana, A. C. P. \& Greghi, S. L. A. Pool of bovine morphogenetic and guided tissue regeneration in the treatment of intrabony periodontal defects. I - Clinical measurements. J. Appl. Oral Sci., 12(1):1-14, 2004.

Ho, S. K.; Peel, S. A.; Hu, Z. M.; Sándor, G. K. \& Clokie C. M. Augmentation of the maxillary sinus: comparison of bioimplants containing bone morphogenetic protein and autogenous bone in a rabbit model. J. Can. Dent. Assoc., 76:a108, 2010.
Iwaniec, U. T.; Trevisiol, C. H.; Maddalozzo, G. F.; Rosen, C. J. \& Turner, R. T. Effects of low-dose parathyroid hormone on bone mass, turnover, and ectopic osteoinduction in a rat model for chronic alcohol abuse. Bone, 42(4):695-701, 2008.

Jung, M. K.; Callaci, J. J.; Lauing, K. L.; Otis, J. S.; Radek, K. A.; Jones, M. K. \& Kovacs, E. J. Alcohol exposure and mechanisms of tissue injury and repair. Alcohol Clin. Exp. Res., 35(3):1-8, 2011.

Mandarin-de-Lacerda, C. A. What is the interest of normal and pathological morphological research to be quantitative? The example of the stereology. Braz. J. Morphol. Sci., 16(2):1319, 1999.

Marin, C.; Granato, R.; Claus, J. D. P; Rivero, E. R. C. \& Gil, J. N. Histological evaluation of inorganic bovine bone graft in maxillary sinus: A case report. Rev. Cir. Traumatol. BucoMaxilo-fac., 7(1):37-42, 2007.

Martins, L. V.; Cestari, T. M; Sottovia, A. D.; Granjeiro, J. M. \& Taga, R. Radiographic and histological study of perennial bone defect repair in rat calvaria after treatment with blocks of porous bovine organic graft material. J. Appl. Oral Sci., 12(1):1-13, 2004.

Marzola, C.; Toledo Filho, J. L.; Zorzetto, D. L. G \& Pastori, C. M. Implantes de BioHapatita + Osseobond + Membrana Reabsorvível Dentoflex + Aglutinante Dentoflex Apresentação de casos clínico-cirúrgicos. Rev. Bras. Cienc. Estomatol., 1(2):51- 63, 1996.

Peel, S. A.; Hu, Z. M. \& Clokie, C. M. In search of the ideal bone morphogenetic protein delivery system in vitro syudies on demineralized bone matrix, purified, and recombinant bone morphogenetic protein. J. Craniof. Surg., 14(3):284-91, 2003.

Tuominen, T.; Jämsä, T.; Tuukkanen, J.; Marttinen, A.; Lindholm, T. S. \& Jalovaara, P. Bovine bone implant with bovine bone morphogenetic protein in healing a canine ulnar defect. Int. Orthop., 25(1):5-8, 2001.

Ueda, M.; Tohnai, I. \& Nakai, H. Tissue engineering research in oral implant surgery. Artif. Organs., 25(3):164-71, 2001.

\section{Correspondence to:}

Rogério Leone Buchaim

University of São Paulo - School of Dentistry of Bauru

Departament of Biological Science

Al. Octávio Pinheiro Brisola, 9-75 -

Bauru - SP

Cep: 17.012-901

BRAZIL

\section{E-mail: rogerio@fob.usp.br}

Received: 20-07-2011

Accepted: 21-11-2011 